\title{
A Tale of Mismanagement at Sea
}

\section{Kai Curry-Lindahl}

Overfishing, wasteful fishing and destructive fishing take a large toll of the fish and all other life in the sea: more than half the important commercial fish species have been overfished; every year several million tonnes of fish and other animals are caught incidentally and discarded, and modern equipment such as bottom trawls and indestructible nylon nets which, lost overboard, become permanent fish traps, spread devastation. Coral reef exploitation, oil exploration, land erosion, dams on major rivers all affect the seas, while much of the agricultural pesticides and the industrial toxic wastes end up there too. Fish provide much-needed animal protein for humans. As more than half the marine productivity is within 200 miles of the shore, which is where 98 per cent of the world's fish catches are made, the need for good management is clearly urgent.

All fishes, freshwater and marine, are good sources of protein. Yet only a small proportion of the protein in our food comes directly from fishes and invertebrates; only 4.4 per cent between 1964 and 1966 . Some is also indirectly taken in the form of fishmeal which is used to feed livestock, captive fur-bearing animals and farmed fishes; in 1970 at least 43 per cent of the world's marine catch was reduced to fishmeal, of which anchoveta Engraulis ringens constituted nearly half. This was the year when the anchoveta catch reached a peak of 13.1 million tonnes, 22 per cent of the world's fish harvest, since when it has declined dramatically. Until the 1970s the fluctuations in anchoveta populations off Peru and Chile were the result of variations in ocean currents, but the collapse of the anchoveta that began then seems to have been due to overfishing, perhaps combined with irregular appearances of the warm current which, in some years, meets the cold Humboldt current. In the years when the warm current pushes the cold water masses, which the anchovetas favour, away from the coast, the consequences are dramatic for the anchoveta; normally they recover, but in the 1970 s the populations did not do so during the optimal cold water periods.

Other important fisheries have also declined spectacularly: the California sardine Sardinops caeruleus; various herring populations Clupea harengus; haddock Gadus aeglefinus and cod G. morhua, and environmental conditions and natural variations alone are not sufficient to explain what has happened. In fact they have been over-exploited, and they have not been able to recover despite the reduced fishing of the last 20-30 years; in 1981 cod catches in the Atlantic were still only a third of their size in the 1960s. At least 25 of the most valuable fisheries in the world have either collapsed or declined substantially as a result of overfishing, and still today more than half the commercially important fish species are over-exploited, although a report by $\mathrm{FAO}^{3}$ put the figure at only 19 , or perhaps 22 , while 58 others are fully exploited. Other depleted species include mackerel Scomber scombrus, Pacific hake Merluccius productus, several sea breams, salmon Salmo salar and Alaska pollack Theragra chalcogramma. This overfishing in international waters, or even inside the territorial limits of the islands of Oceania and along African and South American coasts, is mostly by fishing fleets from industrialized countries, notably Japan, USSR, 
and Korea. When the stocks are depleted, the fleets move on. Will capelin Mallotus villosus be the next victim? Of the eight major depleted sea regions of the world - north-west, south-east, east-central and south-west Atlantic, Mediterranean, north-west, north-east and south-east Pacific - seven are dominated by fishing fleets from developed countries even though three are in the Third World.

Overfishing is a major cause of depletion. So is waste. This occurs at almost every stage from capture to consumption. Enormous quantities of 'trash' fish and invertebrates are caught in trawls and discarded, dead and dying, at sea, because there is no market demand for their size and/or species. Thus several tonnes of 'trash' fish and other animals are killed for every tonne of shrimp caught and frozen. Purse-seine fisheries can be very wasteful: hauls of shoal fishes, such as mackerel, are often too large to be handled by the boat, and little or none of the catch may be taken; entire catches are also 'slipped' if the haul contains too many fish of unwanted species or the wrong sizes of the target species; most of the returned catch, often juveniles of commercial fish, die from shock, suffocation or injury. One estimate puts the amount of fish destroyed in this way at about 7 million tonnes a year, or about 10 per cent of the weight of fish caught and landed. In Africa, marketing and processing wastes are probably higher, with up to 50 per cent of the product lost, the average being about 15 per cent. ${ }^{8}$ In economic terms, the proportion of waste in the total utilization of fishes can in many cases approach 80 per cent of production costs. ${ }^{2}$

\section{Dolphins and Dugongs Die Needlessly}

Other great losses occur among marine vertebrates. In the Pacific, tens of thousands of tonnes of dolphins are killed every year by purse-seine fishing for the yellow-fin tuna Thunnus albacares and, with the notable exception of the United States, most nations refuse even to report the numbers of dolphins taken, which would raise a public outcry. On tropical coasts the endangered dugong Dugong dugon is caught in fish nets and shark barriers wherever it occurs, and sea-turtles are often caught in bottom trawls, seines and gill-nets; the meat of such drowned animals is often unsuitable for human consumption.

Birds too are victims. Every year about one million sea-birds are killed incidentally by fishing nets; many are species that provide food for humans, either as eggs or adults. The decline of the east Pacific anchoveta fishery has resulted in a tremendous decline in guano-producing birds. Between 1946 and 1950 the populations of the guanay cormorant Phalacrocorax bougainvillii, Peruvian booby Sula variegata, and the brown pelican Pelecanus occidentalis on the Chincha Islands, off Peru, were estimated at about 35 million. They consumed two or three million tonnes of anchovetas per year, but the large quantities of guano they produced was exported as fertilizer and was of great economic importance to Peru. Since 1955 the fishing industry has been invaded by multimillion-dollar companies. Overfishing of the anchoveta has brought disaster to the sea-birds. Between 1957 and 1958 over 13 million birds died, many drowned in fishing nets; this was 64 per cent of the population, and by 1965 only 4 million were left, a fifth of their former number. The collapse of the guano industry has had serious economic and social consequences for Peru. This story is an outstanding example of the complex relationship between a marine ecosystem and Man as a consumer.

Now it is the turn of the krill. With the backing of FAO and UNDP, eight or 


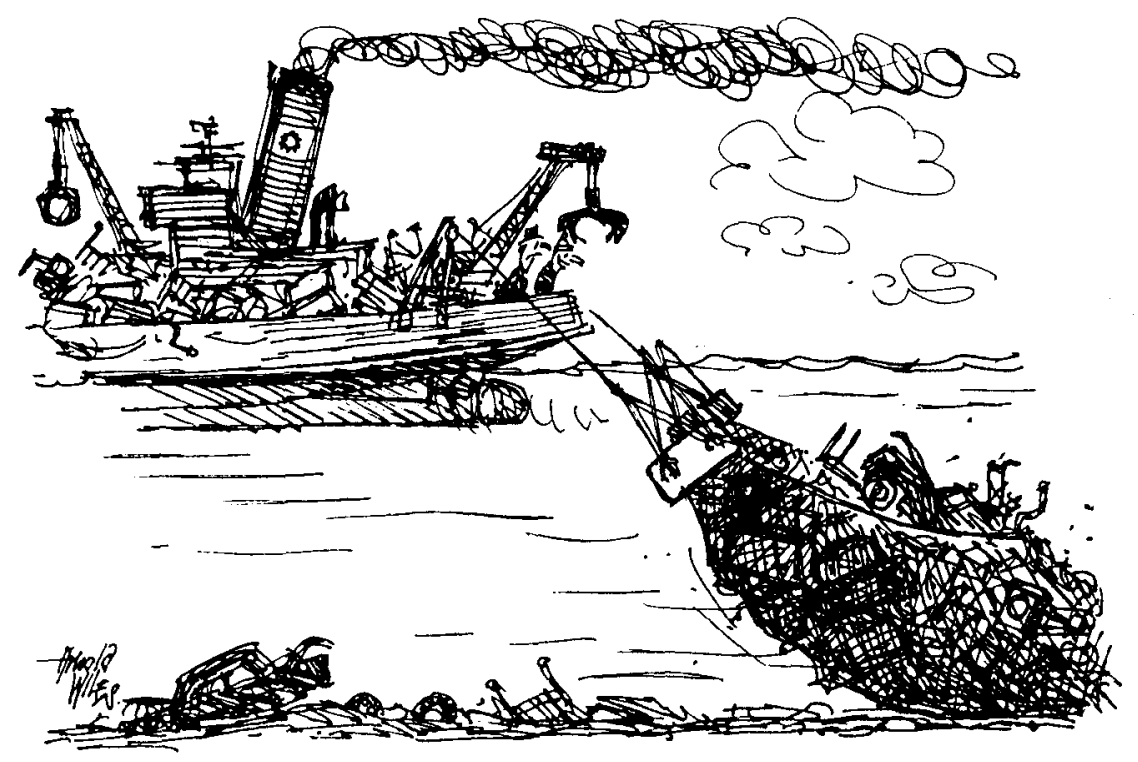

"We gave up fishing long ago. We're into scrap these days."

Cartoon from Marine Pollution Bulletin December 1981, reproduced by kind permission of Pergamon Press Ltd.

more countries have been exploring the possibility of exploiting krill Euphausia superba in the Antarctic Ocean. In 1977-78 the krill catch was about 50,000 tonnes; some estimates suggest it could rise to 60 million tonnes, which is more than the current world fish catch. A surplus is assumed because several baleen whales which feed on krill have almost vanished from the Antarctic Ocean owing to their reckless depletion, mainly by Japan and the USSR. The 'surplus theory' is a typical commercial presumption by whaling nations seeking new resources for their vessels to exploit. But whales are not the only animals to prey on krill; seals, penguins, fishes and squid also do so, and the commercial exploitation of krill and other plankton in the Antarctic could have a serious impact on the ecosystem there and in other oceans, affecting nations other than those harvesting the krill. From 1975 to 1977 UNEP repeatedly warned FAO and UNDP about their projects to develop the technology for commercial harvesting of krill before their ecology and population dynamics and that of their predators had been fully investigated. Sidney Holt rightly says:

'It might be reasonably argued that it would be much better to leave the Southern Ocean in its relatively pristine state for the time being, while the great whales recover, while mankind learns much more about the dynamics of that rich biological system, and while strong international institutions are developed, which would one day be capable of organizing a rational use of the area for the benefit of mankind. Such use might or might not involve the capture of whales as food; it might or might not involve the harvesting of krill, the slaughter of seals for fur and/or meat, and the economic utilization of other animals inhabiting the Southern Ocean. ${ }^{4}$ 
Overcapitalization in commercial fishing and marketing have undoubtedly contributed to the decline of fish and other marine resources. ${ }^{1}$ It is notable that, in recent years, the registered tonnage of fishing vessels has increased at twice the rate of the level of the fish catches. Now the Antarctic krill-fishing may lead to large investments in fishing fleets which, even if the krill declines, will continue fishing just for the sake of these investments, as happened with the whales.

The continued destruction of marine, particularly coastal, habitats is another menace to productivity. Many commercially important fishes, crustaceans and molluscs feed, spawn, or spend their early life around coral reefs, in lagoons, sea-grass beds, mangrove forests, tidal estuaries, or coastal wetlands. Two-thirds of the world's marine fisheries depend on organisms in these highly-productive systems $;{ }^{7}$ sometimes the proportion is even higher, as in the Gulf of Mexico where it is 97 per cent. In the USA damage to marine fisheries through coastal wetland destruction has been estimated at almost $\$ 86$ million a year. ${ }^{5,6}$ It would be better to utilize and manage these ecosystems wisely rather than trying to rehabilitate them after they have been destroyed but, unfortunately, quick economic returns dominate the considerations of governments and of development aid organizations.

Fishing gear also destroys marine habitats and their fishes, although the extent of damage cannot always be measured, because it is 'invisible'. Heavy bottom trawls are towed repeatedly over the sea bed, indiscriminately crushing everything, including its inhabitants. Lost trammel and gill-nets brought up later have been full of decomposing fish. Modern nylon nets do not disintegrate, but act as permanent traps for unknown quantities of fishes. Similarly, dredging for 'coral sand', real sand and gravel destroys habitats and the eggs, larvae and adults of many fishes and has killed entire coral reefs. So has fishing with dynamite. During the last decade development aid has been used to install crushers of "coral sand' in many tropical countries, and dead and live reefs are ground up. Coral reefs have been dynamited to provide bathing places for tourists. This disturbs the circulation, and the beach is washed away, defeating the purpose of the exercise. Corals are harvested for decoration and sale as curios to tourists, a practice that has seriously decimated miles of reefs, especially in the Caribbean, Africa and Asia. Several studies have shown the serious consequences of coral reef destruction. A productive ecosystem is wiped out, and the productivity of the lagoons and the stability of the shore may be seriously affected, with grave social consequences, as in Oceania.

Other forms of development have affected fish productivity in lagoons. On tropical islands and coasts large fish-storage freezers, built with funds from the World Bank and other international aid organizations, have led to the introduction of commercial fishing in the lagoons and off coral reefs where traditionally fishing was for local subsistence only. To ensure the return on these large investments the freezers have to be constantly used and filled with fish so that foreign ships can load without waiting. The result has been serious depletion of stocks in the lagoons and a collapse of the traditional fishery on which local people depended.

Oil spills and underwater leaks from oil-wells have had disastrous effects on valuable marine life, and so too have some man-made changes hundreds of miles inland. River banks cleared of forest and vegetation erode quickly, and tonnes of fertile soil are washed down to the sea, where they may kill or reduce the 
productivity of coral reef ecosystems, by limiting light or by mechanical damage. Dams on rivers and estuaries inhibit the migration of fishes and may prevent nutrients reaching the sea. In the eastern Mediterranean, for example, the building of the Aswan Dam on the Nile has caused the collapse of the sardine fishery off Egypt and the decline of fisheries around Cyprus.

\section{Poisoning the Sea}

Several persistent toxic chemicals are directly lethal to marine organisms including higher vertebrates, but they also poison whole ecosystems, partly by accumulation in the water, and partly because they travel along food-chains and are increasingly concentrated in successive consumers. Persistent biocides such as DDT, aldrin, dieldrin, endrin, lindane, heptachlor and chlordane, are not broken down even after 10-15 years, and small quantities can be fatal or lead to reproductive failure and abnormal behaviour. Mercury and PCBs are also particularly harmful in the sea; in the Baltic PCBs are in the process of exterminating the fish-eating gray seal Halichoerus grypus and ringed seal Phoca hispida botnica. Little is known about the effects of toxic chemicals on sea-fishes, although there are examples of severe methyl mercury poisoning in tuna Thunnus thynnus and swordfish Xiphias gladius. Green algae, molluses, crustaceans, sea-birds, seals and whales are all very sensitive to toxic substances. Several sea-bird species feeding on marine fish have accumulated toxic chemicals in their tissues with catastrophic effects on their reproduction. Biocides and fertilizers and industrial toxic wastes often end up in the sea.

Another hazard is the introduction of exotic fish species, which the Russians have done in the Baltic and Arctic without consulting or warning their neighbours.

The malpractices and unwise exploitation goes on despite the great number of international fishery agreements dealing with conservation and management that are in force. Will the current UN Conference on the Law of the Sea (UNCLOS), ongoing since 1958, yield new concepts to solve ecological problems related to living marine resources, or, is it more concerned, as Holt has suggested, ${ }^{4}$ with appropriating resources rather than conserving or protecting them, more with rights than with responsibilities, 'more with the distribution of benefits among coastal states, developed and developing alike, than with global equity'?

\section{Unexploited Resources are Not Wasted}

Marine national parks and reserves so far are all in coastal waters - the Indian Ocean Sanctuary is only for the protection of some whale species. But we need to preserve ecosystems and the ecological processes that are often vital for real understanding and as reference areas for comparison with areas affected by man; and this means strict nature reserves on the continental shelves and in the open sea. The resources of the sea must be considered and assessed ecologically by those who want to exploit them. For example, plankton, because of its key position in the food-chains, is economically the most valuable ocean species, but little is known about the dynamics and movements of plankton populations. Much more research is required before we understand how to tap these resources wisely, either directly or indirectly. Food-webs are complex and marine ecosystems are vulnerable to intense human exploitation of key organisms. The whole marine environment is seriously threatened, and particularly is this true of the territorial seas up to about $320 \mathrm{~km}$ ( 200 miles) offshore, where more than half the biomass of the sea is produced and where 98 per cent of the total world 
fish catch is made. To a great extent this catch has been taken off the coasts of developing countries - particularly in upwelling areas -- by developed countries for their own use, either as human food or increasingly for animal food - pets, livestock, fur-bearing animals and cultured trout.

Many development projects have been designed to exploit natural resources, usually without studying their natural productivity and its foundations, or their significance for neighbouring resources already in use. This still happens, despite the often terrifying results. The 'opening-up' process makes dramatic changes and the environment deteriorates rapidly. Whenever plans for exploiting a marine area mean inevitable devastation alternative means of utilizing the natural resources should be explored. Even more important, before a decision is taken to exploit a new area or resource, it must be determined whether a greater yield can be obtained in the long term by improved management and fishing techniques in existing fisheries. All too often it is assumed that any unexploited natural resource, marine, freshwater or terrestrial, is being wasted. In fact it is often thanks to this untapped resource that adjacent areas and resources are still productive and fertile.

\section{References}

1. CLARK, C.W. 1977. Overcapitalization in commercial fisheries: symptoms, causes and cures. Env. Biol. Fish. 2: 3-5.

2. CONSTANTINIDES, S.M. 1975. Marine Food Science and Technology. In A.S. Msangi and J.J. Griffin (ed.): International Conference on Marine Resources Development in Eastern Africa, pp. 107-10, Dar es Salaam.

3. FAO. 1979. Committee on Fisheries. Paper COF/1/79. Inf. 4.

4. HOLT, S. 1977. A contribution to discussion of a new economic order with reference to the living resources of the ocean. FAO, Rome, 46pp.

5. HESTER, F.J. 1976. Economic aspects of the effects of pollution on the marine and anadromous fisheries of the western United States of America. FAO Fisheries Technical Paper. 162.

6. KUMPF, H.E. 1977. Economic impact of the effects of pollution on the coastal fisheries of the Atlantic and Gulf of Mexico regions of the United States of America. FAO Fisheries Technical Paper. 172: I-VII + 1-79.

7. McHUGH, J.L. 1966. Management of estuarine fisheries. Special Publications of the American Fisheries Society. 3: 133-54.

8. MSANGI, A.S. and J.J. GRIFFIN. 1975. International Conference on Marine Resources Development in Eastern Africa. 130pp. Dar es Salaam.

Professor Kai Curry-Lindahl, Department for Forestry and Resource Management, College of Natural Resources, University of California, Berkeley, California 94720, USA.

\section{Securing a Future for the Barbary Macaque}

The Barbary macaque Macaca sylvanus was the subject of a three-day conference in Gibraltar last June which brought together experts on primates and conservation to formulate ways of protecting the monkey. Key points to emerge were the need for further research on the factors affecting distribution, on population densities and carrying capacities of all habitats, on long-term studies of population dynamics and on the translocation of surplus stock to the wild. Potential conservation areas and national parks were identified and help requested from international agencies. The conference was organized by John $\mathrm{E}$. $\mathrm{Fa}$, under the auspices of the Primate Society of Great Britain Working Party for Conservation, and sponsored by IUCN, WWF and ff PS. 